Open Access

\title{
Prevalence and risk factors for cancer of the uterine cervix among women living in Kinshasa, the Democratic Republic of the Congo: a cross-sectional study
}

\author{
Catherine Ali-Risasi ${ }^{1,2^{*}}$, Kristien Verdonck ${ }^{3}$, Elizaveta Padalko ${ }^{4,5}$, Davy Vanden Broeck ${ }^{6}$ and Marleen Praet $^{2}$
}

\begin{abstract}
Background: Cancer of the uterine cervix is the leading cause of cancer-related death among women in Sub-Saharan Africa, but information from the Democratic Republic of the Congo (DRC) is scarce. The study objectives were to: 1/ assess prevalence of (pre)cancerous cervical lesions in adult women in Kinshasa, 2/ identify associated sociodemographic and behavioural factors and 3/ describe human papillomavirus (HPV) types in cervical lesions.

Methods: A cross-sectional study was conducted in Kinshasa. Between 2006 and 2013, four groups of women were recruited. The first two groups were included at HIV screening centres. Group 1 consisted of HIV-positive and group 2 of HIV-negative women. Group 3 was included in large hospitals and group 4 in primary health centres. Pap smears were studied by monolayer technique (Bethesda classification). Low- or high-grade squamous intraepithelial lesions or carcinoma were classified as LSIL+. HPV types were determined by INNO-LiPA ${ }^{\oplus}$. Bivariate and multivariable analyses (logistic regression and generalised estimating equations (GEE)) were used to assess associations between explanatory variables and LSIL+.

Results: LSIL+ lesions were found in 76 out of 1018 participants. The prevalence was $31.3 \%$ in group 1 ( $n=131$ HIV-positive women), $3.9 \%$ in group 2 ( $n=128 \mathrm{HIV}$-negative women), $3.9 \%$ in group $3(n=539)$ and $4.1 \%$ in group $4(n=220)$. The following variables were included in the GEE model but did not reach statistical significance: history of abortion, $\geq 3$ sexual partners and use of chemical products for vaginal care. In groups 3 and 4 where this information was available, the use of plants for vaginal care was associated with LSIL+ (adjusted OR 2.70 (95\% confidence interval 1.04 - 7.01). The most common HPV types among HIV-positive women with ASCUS+ cytology (ASCUS or worse) were HPV68 (12 out of 50 samples tested), HPV35 (12/50), HPV52 (12/50) and HPV16 (10/50). Among women with negative/unknown HIV status, the most common types were HPV52 (10/40), HPV35, (6/40) and HPV18 (5/40).
\end{abstract}

Conclusion: LSIL+ lesions are frequent among women in Kinshasa. The use of plants for vaginal care deserves attention as a possible risk factor for LSIL+. In this setting, HPV16 is not the most frequent genotype in samples of LSIL+ lesions.

Keywords: Cervical intraepithelial neoplasia, Human papillomavirus, Risk factors, Cross-sectional studies, Democratic Republic of the Congo

\footnotetext{
*Correspondence: cathymulumba@yahoo.fr

'Laboratory of Anatomopathology, General Reference Hospital of Kinshasa,

Kinshasa, Democratic Republic of the Congo

${ }^{2}$ N.Goormaghtigh Institute of Pathology, Ghent University Hospital, De

Pintelaan 185, Ghent, Belgium

Full list of author information is available at the end of the article
} 


\section{Background}

Cervical cancer constitutes a major health problem worldwide. It is responsible for 530,000 new cases of cancer and causes 270,000 deaths each year [1,2]. Up to $80-85 \%$ of cervical cancer-related deaths occur in low-income countries [1, 3]. In African women, it is the second most common cancer after breast cancer with an incidence rate of about 25 per 100,000 women per year. In Sub-Saharan Africa the incidence rate amounts to about $30-35$, and here it is the most frequent cancer in women (for African data see [3-6]). It is expected, even on demographic grounds, that the burden of cervical cancer will further increase in Africa over the next years [7]. In contrast, in high-income countries such as the US and Europe the age-standardized incidence rate is about 6 to 10 per 100,000 women per year $[1,2]$. Also the number of deaths from cervical cancer is nearly ten times lower in high-income countries $[8,9]$. Differences between low- and high-income countries have been related to differences in exposure to risk factors and adequacy of screening. The most important risk factor is human papillomavirus (HPV) infection. Several other factors have been found to increase the risk of cervical cancer, possibly through their relation with the risk of HPV infection: number of sexual partners, early sexual activity [10], parity [11], long-term use of oral contraceptives [12-14], smoking [15] and HIV/AIDS [16-18].

The link between cervical cancer and HPV infection has been well established [16, 19-22]. From the more than 100 types of HPV described, about 40 are known to infect the genital tract and about 20 have been classified as oncogenic to humans [23-25]. Persistent infection with high-risk HPV has been considered as the necessary condition for malignant transformation of the cervical epithelium. In most studies, HPV16 and HPV18 are the predominant genotypes: they cause about $70 \%$ of precancerous lesions and cervical cancer [26]. In SubSaharan Africa however, other oncogenic genotypes have been reported [22, 27-32].

In most Sub-Saharan countries, data on the prevalence and mortality of cervical cancer are either sparse or unavailable. Only $17 \%$ of African countries have a national programme and a specific budget for fighting cervical cancer. And where such a cervical cancer programme exists, the effective coverage may be low. In addition, those women at the highest risk of developing cervical cancer may have the most difficult access to care [33, 34]. The prevalence of precancerous and cancerous lesions has been studied in a small number of women in the Democratic Republic of the Congo (DRC) [35-40]. Some of these reports include the prevalence of HPV and/or cervical lesions in HIV-positive women [35, 40].

Because of the high burden of cervical cancer in SubSaharan Africa, and presumably also in the DRC, the primary objectives of this study were to: $1 /$ evaluate the prevalence of (pre)cancerous lesions, 2/ identify associated socio-demographic and behavioural factors and 3/ describe HPV types present among women in Kinshasa.

\section{Results}

\section{Characteristics of study participants}

The total number of participants was 1018. One hundred thirty-one HIV-positive women were recruited at HIV screening centres (group 1); 128 HIV-negative women came from the same HIV screening centres (group 2); 539 women were recruited at large hospitals (group 3); and 220 were referred through small health centres (group 4). The HIV status of the women in groups 3 and 4 was unknown.

Table 1 shows the age and age-related characteristics of the participants. The mean age for all participants was 43.0 years $( \pm 12.8$ standard deviation $(\mathrm{SD}))$. The mean age of menarche was 14.3 years $( \pm 1.9)$ and the age of the first sexual intercourse was 18.5 years $( \pm 3.9)$. Table 2 summarises the socio-demographical characteristics of the study population. About half of the women were married, with the highest percentage in group $3(61.2 \%)$ and the lowest in group $2(20.3 \%)$. About one in six women was widowed $(18.0 \%)$, and one in four was single. Concerning pregnancies and parity, $44.0 \%$ of the women reported six or more pregnancies, $29.8 \%$ responded to have six or more children and $60.7 \%$ reported to have had an abortion (not specified whether spontaneously or not).

Behaviour-related characteristics of the study population are shown in Table 3. About half of the participants reported to have had zero to two lifetime sexual partners. In groups 1 and 2 (recruited at HIV screening centres), more women reported to have had three or more sexual partners (65.4\% and $61.2 \%$ respectively). One out of five women declared to have used hormonal contraceptives (19.2\%); no information is available on the duration of its use. One out of four women reported alcohol consumption, including regular as well as irregular use. About the same percentage $(26.0 \%)$ reported to use chemical products for vaginal care. The women in groups 3 and 4 were also asked about the use of plants for vaginal care: $11.4 \%$ of the women confirmed the intravaginal application of plants or vegetable products. Although the structured interview did not include specific questions about the type of plants that were used, some interviewers took note of what some of the women reported. Terms that were mentioned repeatedly in the local language Lingala included: mbonzi-mbonzi (leaves of a tree), tangawisi (ginger), tomate (tomato), lumba-lumba (medicinal leaves) and ngai-ngai (sorrel).

\section{Prevalence of low-grade squamous intraepithelial lesions or worse (LSIL+)}

In total, 76 of 1018 women were diagnosed with LSIL+ lesions (i.e. low- or high-grade squamous intraepithelial 
Table 1 Age-related characteristics of the study population

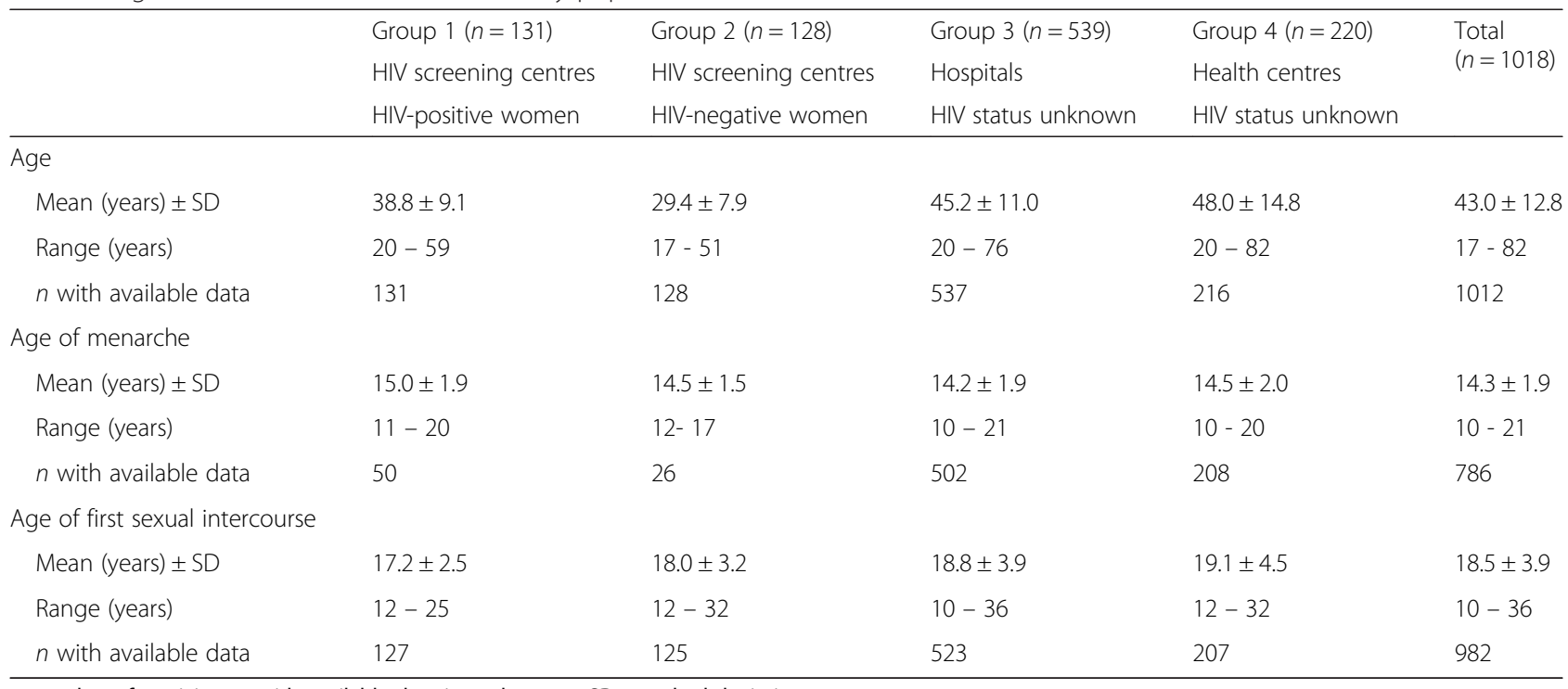

$n$ : number of participants with available data in each group; SD: standard deviation

Table 2 Socio-demographic characteristics of the study population

\begin{tabular}{|c|c|c|c|c|c|c|c|c|c|c|}
\hline & \multirow{3}{*}{\multicolumn{2}{|c|}{$\begin{array}{l}\text { Group } 1(n=131) \\
\text { HIV screening centres }\end{array}$}} & \multirow{2}{*}{\multicolumn{2}{|c|}{$\begin{array}{l}\text { Group } 2(n=128) \\
\text { HIV screening centres }\end{array}$}} & \multirow{3}{*}{\multicolumn{2}{|c|}{$\begin{array}{l}\text { Group } 3(n=539) \\
\text { Hospitals } \\
\text { HIV status unknown }\end{array}$}} & \multirow{3}{*}{\multicolumn{2}{|c|}{$\begin{array}{l}\text { Group } 4(n=220) \\
\text { Health centres } \\
\text { HIV status unknown }\end{array}$}} & \multirow{3}{*}{\multicolumn{2}{|c|}{$\begin{array}{l}\text { Total } \\
(n=1018)\end{array}$}} \\
\hline & & & & & & & & & & \\
\hline & & & \multicolumn{2}{|c|}{ HIV-negative women } & & & & & & \\
\hline & $n$ & $\%$ & $n$ & $\%$ & $n$ & \multirow[t]{2}{*}{$\%$} & \multirow{2}{*}{$\frac{n}{217}$} & \multirow[t]{2}{*}{$\%$} & $n$ & $\%$ \\
\hline Marital status & 130 & & 128 & & 533 & & & & 1008 & \\
\hline Married & 43 & (33.1) & 26 & $(20.3)$ & 326 & $(61.2)$ & 120 & $(55.3)$ & 515 & $(51.1)$ \\
\hline Single & 39 & $(30.0)$ & 95 & $(74.2)$ & 76 & $(14.3)$ & 33 & $(15.2)$ & 243 & $(24.1)$ \\
\hline Widowed & 34 & $(26.2)$ & 4 & (3.1) & 92 & $(17.3)$ & 51 & $(23.5)$ & 181 & (18.0) \\
\hline Divorced & 14 & $(10.8)$ & 3 & $(2.3)$ & 39 & (7.3) & 13 & $(6.0)$ & 69 & $(6.9)$ \\
\hline Formal employment & 129 & & 126 & & 525 & & 215 & & 995 & \\
\hline No & 73 & $(56.6)$ & 67 & $(53.2)$ & 225 & $(42.9)$ & 109 & $(50.7)$ & 474 & $(47.6)$ \\
\hline Yes & 56 & $(43.4)$ & 59 & $(46.8)$ & 300 & $(51.7)$ & 106 & $(49.3)$ & 521 & $(52.4)$ \\
\hline Number of pregnancies & 128 & & 126 & & 517 & & 219 & & 990 & \\
\hline $0-2$ & 29 & $(22.7)$ & 87 & $(69.1)$ & 131 & $(25.3)$ & 53 & $(24.2)$ & 300 & $(30.3)$ \\
\hline $3-5$ & 42 & (32.8) & 28 & $(22.2)$ & 124 & $(24.0)$ & 60 & $(27.4)$ & 254 & $(25.7)$ \\
\hline 6 or more & 57 & $(44.5)$ & 11 & $(8.7)$ & 262 & $(50.7)$ & 106 & $(48.4)$ & 436 & $(44.0)$ \\
\hline Number of childbirths & 128 & & 126 & & 520 & & 218 & & 992 & \\
\hline $0-2$ & 48 & $(37.5)$ & 100 & $(79.4)$ & 190 & $(36.5)$ & 70 & $(32.1)$ & 408 & $(41.1)$ \\
\hline $3-5$ & 41 & $(32.0)$ & 20 & $(15.9)$ & 161 & $(31.0)$ & 66 & (30.3) & 288 & $(29.0)$ \\
\hline 6 or more & 39 & $(30.5)$ & 6 & $(4.8)$ & 169 & $(32.5)$ & 82 & $(37.6)$ & 296 & $(29.8)$ \\
\hline Abortion & 128 & & 126 & & 518 & & 218 & & 990 & \\
\hline No & 48 & (37.5) & 61 & $(48.4)$ & 175 & (33.8) & 105 & $(48.2)$ & 389 & (39.3) \\
\hline Yes & 80 & $(62.5)$ & 65 & $(51.6)$ & 343 & $(66.2)$ & 113 & $(51.8)$ & 601 & (60.7) \\
\hline
\end{tabular}

$n$ : absolute number; \%: percentage of participants in each study group and each category 
Table 3 Behaviour-related characteristics of the study population

\begin{tabular}{|c|c|c|c|c|c|c|c|c|c|c|}
\hline & \multirow{2}{*}{\multicolumn{2}{|c|}{$\begin{array}{l}\text { Group } 1(n=131) \\
\text { HIV screening centres }\end{array}$}} & \multirow{2}{*}{\multicolumn{2}{|c|}{$\begin{array}{l}\text { Group } 2(n=128) \\
\text { HIV screening centres }\end{array}$}} & \multirow{2}{*}{\multicolumn{2}{|c|}{$\begin{array}{l}\text { Group } 3(n=539) \\
\text { Hospitals }\end{array}$}} & \multirow{3}{*}{\multicolumn{2}{|c|}{$\begin{array}{l}\text { Group } 4(n=220) \\
\text { Health centres } \\
\text { HIV status unknown }\end{array}$}} & \multirow{2}{*}{\multicolumn{2}{|c|}{$\begin{array}{l}\text { Total } \\
(n=1018)\end{array}$}} \\
\hline & & & & & & & & & & \\
\hline & \multicolumn{2}{|c|}{ HIV-positive women } & \multicolumn{2}{|c|}{ HIV-negative women } & \multicolumn{2}{|c|}{ HIV status unknown } & & & & \\
\hline & $n$ & $\%$ & $n$ & $\%$ & $n$ & $\%$ & $n$ & $\%$ & $n$ & $\%$ \\
\hline Number of sexual partners & 129 & & 127 & & 529 & & 190 & & 975 & \\
\hline Zero to two & 50 & $(38.8)$ & 44 & $(34.7)$ & 304 & $(57.5)$ & 132 & $(69.5)$ & 530 & $(54.4)$ \\
\hline Three or more & 79 & $(61.2)$ & 83 & $(65.4)$ & 225 & $(42.5)$ & 58 & $(30.5)$ & 445 & $(45.6)$ \\
\hline Use of hormonal contraception & 131 & 131 & 128 & & 539 & & 171 & & 969 & 969 \\
\hline No & 105 & $(80.2)$ & 118 & $(92.2)$ & 421 & $(78.1)$ & 139 & $(81.3)$ & 783 & $(80.8)$ \\
\hline Yes & 26 & $(19.8)$ & 10 & $(7.8)$ & 118 & $(21.9)$ & 32 & $(18.7)$ & 186 & $(19.2)$ \\
\hline Alcohol consumption & 131 & & 127 & & 529 & & 138 & & 925 & 925 \\
\hline No & 123 & $(93.9)$ & 99 & $(78.0)$ & 378 & $(71.5)$ & 87 & $(63.0)$ & 687 & $(74.3)$ \\
\hline Yes & 8 & $(6.1)$ & 28 & $(22.1)$ & 151 & $(28.5)$ & 51 & $(37.0)$ & 238 & $(25.7)$ \\
\hline Use of plants for vaginal care & & & & & 539 & & 212 & & 751 & 751 \\
\hline No & & & & & 513 & $(95.2)$ & 153 & $(72.2)$ & 666 & (88.6) \\
\hline Yes & & & & & 26 & $(4.8)$ & 59 & $(27.8)$ & 85 & $(11.4)$ \\
\hline $\begin{array}{l}\text { Use of chemical products for } \\
\text { vaginal care }\end{array}$ & 131 & & 128 & & 539 & & 151 & & 949 & \\
\hline No & 98 & $(74.8)$ & 92 & $(71.9)$ & 445 & $(82.6)$ & 67 & $(44.4)$ & 702 & $(74.0)$ \\
\hline Yes & 33 & $(25.2)$ & 36 & $(28.1)$ & 94 & $(17.4)$ & 84 & (55.6) & 247 & (26.0) \\
\hline
\end{tabular}

$n$ : absolute number; \%: percentage of participants in each study group and each category

lesions (LSIL or HSIL) or invasive cancer, Table 4). Among the HIV-positive women of group 1, the prevalence of LSIL+ was $31.3 \%$ (95 \% confidence interval (CI): $24.0 \%$ $39.7 \%)$. Among the HIV-negative women recruited in the same clinics (group 2), the LSIL+ prevalence was $3.9 \%$ (95\% CI: $1.7 \%-8.8 \%$ ). Among the participants coming from the large hospitals (group 3), the prevalence was
3.9 \% (95 \% CI: $2.6 \%-5.9 \%$ ) and among the women coming via smaller health centres (group 4), $4.1 \%$ (95\% CI: $2.2 \%-7.6 \%$ ). Among the women with unknown or negative HIV status, lesions classified as ASCUS (atypical squamous cells of undetermined significance) or ASC-H (atypical squamous cells, cannot rule out high-grade lesion) were more frequent than LSIL+ lesions (Table 4).

Table 4 Numbers and proportions of different lesions according to the Bethesda 2001 classification, per study group

\begin{tabular}{|c|c|c|c|c|c|}
\hline & Group $1(n=131)$ & Group $2(n=128)$ & Group $3(n=539)$ & Group $4(n=220)$ & \multirow{3}{*}{$\begin{array}{l}\text { Total } \\
(n=1018)\end{array}$} \\
\hline & HIV screening centres & HIV screening centres & Hospitals & Health centres & \\
\hline & HIV-positive women & HIV-negative women & HIV status unknown & HIV status unknown & \\
\hline & $n(\%)$ & $n(\%)$ & $n(\%)$ & $n(\%)$ & 1018 (\%) \\
\hline NILM & $80(61.1)$ & 117 (91.4) & 449 (83.3) & $188(85.5)$ & $834(81.9)$ \\
\hline ASCUS & $9(6.9)$ & $5(3.9)$ & $46(8.5)$ & $19(8.6)$ & $79(7.8)$ \\
\hline ASC-H & $1(0.8)$ & $1(0.8)$ & $23(4.3)$ & $4(1.8)$ & $29(2.9)$ \\
\hline LSIL & $2(1.5)$ & $0(0.0)$ & $0(0.0)$ & $0(0.0)$ & $2(0.2)$ \\
\hline $\mathrm{HSIL}$ & $30(22.9)$ & $5(3.9)$ & $17(3.2)$ & $5(2.3)$ & $57(5.6)$ \\
\hline $\mathrm{Ca}$ & $9(6.9)$ & $0(0.0)$ & $4(0.7)$ & $4(1.8)$ & $17(1.7)$ \\
\hline Subtotal: LSIL+ & $41(31.3)$ & $5(3.9)$ & $21(3.9)$ & $9(4.1)$ & $76(7.5)$ \\
\hline
\end{tabular}

NILM negative for intraepithelial lesion and malignancy

ASCUS atypical squamous cells of undetermined significance

ASC-H atypical squamous cells, cannot rule out high-grade lesion

LSIL low-grade squamous intraepithelial lesion

HSIL high-grade squamous intraepithelial lesion

Ca Carcinoma

LSIL+ cytology findings compatible with (pre)cancerous lesions (includes low- and high-grade squamous intraepithelial lesions and carcinoma) 


\section{Socio-demographic factors and behaviour characteristics associated with LSIL+ lesions}

In each of the four groups, bivariate associations were assessed between all explanatory factors (age, sociodemographic and behaviour-related characteristics) and the presence of LSIL+ lesions. Crude odds ratios (ORs) are given in Table 5. Explanatory factors with a $P$-value of $<0.2$ were included in a model of multiple logistic regression (one model per study group). The adjusted ORs are given in Table 6. None of these associations reached statistical significance on multiple logistic regression.

All participants were then analysed together using generalised estimating equations (GEE) to account for clustering within the study groups. Also in the GEE analysis, all factors with a $P$-value $<0.2$ on bivariate evaluation were included in a multivariable model. The final GEE model (one model for all the study groups) included history of abortion (adjusted OR 1.60; 95 \% CI
0.97 - 2.63), more than three sexual partners (adjusted OR 1.29; 95 \% CI 0.83 - 1.99) and use of chemical products for vaginal care (adjusted OR 0.65; 95 \% CI 0.37 1.14). Adding age to the model did not substantially change the ORs. None of the associations in this model reached statistical significance (Table 6).

The use of plants for vaginal care could only be evaluated in groups 3 and 4 because this information was not available for the women in the other groups. In a multiple logistic regression model including the use of plants, alcohol consumption and having had three or more sexual partners, the adjusted OR for the association between the use of plants for vaginal care and the presence of LSIL+ lesions was 2.70 (95\% CI 1.04 - 7.01; Table 6).

\section{Determination of HPV DNA and HPV typing}

The following cytology results were classified as ASCUS+ and the corresponding samples were submitted for HPV

Table 5 Bivariate associations between socio-demographic and behavioural characteristics and presence of LSIL+ lesions, per study group

\begin{tabular}{|c|c|c|c|c|c|c|c|c|c|}
\hline & & \multirow{3}{*}{\multicolumn{2}{|c|}{$\begin{array}{l}\text { Group } 1(n=131) \\
\text { HIV screening centres } \\
\text { HIV-positive women }\end{array}$}} & \multicolumn{2}{|c|}{ Group $2(n=128)$} & \multicolumn{2}{|c|}{ Group $3(n=539)$} & \multicolumn{2}{|c|}{ Group $4(n=220)$} \\
\hline & & & & \multicolumn{2}{|c|}{ HIV screening centres } & \multicolumn{2}{|l|}{ Hospitals } & \multicolumn{2}{|c|}{ Health centres } \\
\hline & & & & \multicolumn{2}{|c|}{ HIV-negative women } & \multicolumn{2}{|c|}{ HIV status unknown } & \multicolumn{2}{|c|}{ HIV status unknown } \\
\hline & & Crude OR & $95 \% \mathrm{Cl}$ & Crude OR & $95 \% \mathrm{Cl}$ & Crude OR & $95 \% \mathrm{Cl}$ & Crude OR & $95 \% \mathrm{Cl}$ \\
\hline Age (in years) ${ }^{a}$ & & 0.99 & $0.95-1.03$ & $1.11^{* *}$ & $1.00-1.24$ & 1.02 & $0.98-1.07$ & 1.02 & $0.97-1.06$ \\
\hline Age of menarche (in years) ${ }^{\mathrm{a}}$ & & 0.94 & $0.67-1.30$ & 2.87 & $0.36-23.07$ & 1.03 & $0.82-1.30$ & 0.80 & $0.55-1.15$ \\
\hline Age of first sexual intercourse & & $0.89^{*}$ & $0.76-1.05$ & 1.09 & $0.86-1.38$ & 1.01 & $0.90-1.13$ & $0.84^{*}$ & $0.68-1.06$ \\
\hline \multirow[t]{4}{*}{ Marital status } & married & 1.00 & & $1.00^{*}$ & & 1.00 & & 1.00 & \\
\hline & single & 0.56 & $0.21-1.48$ & 0.82 & $0.08-8.18$ & 2.23 & $0.74-6.71$ & 1.23 & $0.24-6.38$ \\
\hline & widowed & 1.16 & $0.45-2.94$ & 8.33 & $0.41-170.67$ & 1.44 & $0.44-4.69$ & $\S$ & \\
\hline & divorced & 0.75 & $0.20-2.79$ & $\S$ & & 1.71 & $0.36-8.10$ & 1.58 & $0.18-14.28$ \\
\hline Formal employment & & 0.75 & $0.35-1.61$ & 1.74 & $0.28-10.79$ & $1.92^{*}$ & $0.73-5.03$ & $0.28^{*}$ & $0.06-1.38$ \\
\hline \multirow[t]{3}{*}{ Number of pregnancies } & $0-2$ & 1.00 & & $1.00^{* *}$ & & 1.00 & & 1.00 & \\
\hline & $3-5$ & 1.31 & $0.47-3.70$ & 1.96 & $0.14-18.04$ & 1.06 & $0.33-3.38$ & 0.28 & $0.03-2.80$ \\
\hline & 6 or more & 1.31 & $0.49-3.51$ & 10.01 & $1.18-75.36$ & 0.66 & $0.22-1.93$ & 0.83 & $0.19-3.59$ \\
\hline \multirow[t]{3}{*}{ Number of childbirths } & $0-2$ & $1.00^{*}$ & & $1.00^{* *}$ & & 1.00 & & 1.00 & \\
\hline & $3-5$ & 1.08 & $0.96-5.77$ & 8.65 & $1.34-55.65$ & 0.31 & $0.15-1.70$ & 0.70 & $0.11-4.31$ \\
\hline & 6 or more & 1.18 & $0.45-3.06$ & $\S$ & & 1.00 & $0.38-2.65$ & 1.15 & $0.25-5.30$ \\
\hline Abortion & & $1.70^{*}$ & $0.77-3.78$ & 1.43 & $0.23-8.85$ & $2.09^{*}$ & $0.69-6.35$ & 1.17 & $0.31-4.48$ \\
\hline Three or more lifetime sexual partners & & 1.26 & $0.58-2.74$ & 2.18 & $0.24-20.10$ & $2.27^{*}$ & $0.92-5.57$ & 0.91 & $0.17-4.82$ \\
\hline Hormonal contraception & & 1.21 & $0.49-3.00$ & 3.17 & $0.32-31.40$ & 1.12 & $0.40-3.12$ & $\S$ & \\
\hline Alcohol consumption & & 0.30 & $0.04-2.49$ & 2.46 & $0.39-15.51$ & 1.57 & $0.64-3.87$ & $4.62^{*}$ & $0.86-24.75$ \\
\hline Plants for vaginal care & & $\dagger$ & & $\dagger$ & & $3.59 *$ & $0.99-13.05$ & 2.15 & $0.56-8.31$ \\
\hline Chemicals for vaginal care & & 0.63 & $0.26-1.55$ & $\S^{*}$ & & 0.49 & $0.11-2.13$ & 2.06 & $0.39-10.95$ \\
\hline $\begin{array}{l}\text { LSIL+: cytology findings compatible with } \\
\text { OR odds ratio; } 95 \% \text { Cl } 95 \% \text { confidence in } \\
\text { aAge was treated as a continuous variable } \\
\text { **P-value of Wald, chi-squared or Fisher er } \\
{ }^{*} P \text {-value of Wald, chi-squared or Fisher ex } \\
\text { §Odds ratio could not be calculated becal } \\
\end{array}$ & $\begin{array}{l}\text { pre)cancerous } \\
\text { terval of the } \\
\text { Interpretatio } \\
\text { kact test }<0.0 \\
\text { act test is not }\end{array}$ & $\begin{array}{l}\text { Is lesions (in } \\
\text { odds ratio } \\
\text { on, e.g. in gr } \\
5 \\
\text { t significant } \\
\text { e cells with }\end{array}$ & $\begin{array}{l}\text { ut is less tha } \\
\text { ut observatio }\end{array}$ & n 0.2 & . & epithe & $11 \mathrm{for}$ & na) & se in age \\
\hline
\end{tabular}


Table 6 Multivariable evaluations of the association between explanatory variables and the presence of LSIL+ lesions

\begin{tabular}{|c|c|c|c|c|c|}
\hline Type of analysis & Study groups included & $\begin{array}{l}\text { Number of } \\
\text { observations* }\end{array}$ & $\begin{array}{l}\text { Explanatory variables included in } \\
\text { the model }\end{array}$ & Adjusted OR & $95 \% \mathrm{Cl}$ \\
\hline \multirow[t]{6}{*}{ Logistic regression } & \multirow{6}{*}{$\begin{array}{l}1 \text { (HIV screening centres } \\
\text { HIV-positive women) }\end{array}$} & \multirow[t]{6}{*}{124} & Age of first sexual intercourse ${ }^{a}$ & 0.86 & $0.72-1.02$ \\
\hline & & & Number of pregnancies & & \\
\hline & & & $0-2$ & 1 & \\
\hline & & & $3-5$ & 0.95 & $0.31-2.86$ \\
\hline & & & 6 or more & 0.83 & $0.28-2.44$ \\
\hline & & & Abortion & 1.98 & $0.83-4.75$ \\
\hline \multirow[t]{10}{*}{ Logistic regression } & \multirow{10}{*}{$\begin{array}{l}2 \text { (HIV screening centres } \\
\text { HIV-negative women) }\end{array}$} & \multirow[t]{10}{*}{123} & $\mathrm{Age}^{\mathrm{a}}$ & 1.11 & $0.95-1.31$ \\
\hline & & & Marital status & & \\
\hline & & & married & 1 & \\
\hline & & & single & 5.26 & $0.27-102.32$ \\
\hline & & & widowed & 4.34 & $0.18-105.99$ \\
\hline & & & divorced & $\S$ & \\
\hline & & & Number of pregnancies & & \\
\hline & & & $0-2$ & 1 & \\
\hline & & & $3-5$ & 1.15 & $0.07-18.34$ \\
\hline & & & 6 or more & 4.27 & $0.22-81.82$ \\
\hline \multirow[t]{4}{*}{ Logistic regression } & \multirow{4}{*}{$\begin{array}{l}3 \text { (Hospitals HIV status } \\
\text { unknown) }\end{array}$} & \multirow[t]{4}{*}{502} & Formal employment & 2.08 & $0.74-5.88$ \\
\hline & & & Abortion & 1.65 & $0.53-5.14$ \\
\hline & & & $\geq 3$ lifetime sexual partners & 1.75 & $0.69-4.46$ \\
\hline & & & Plants for vaginal care & 2.85 & $0.75-10.82$ \\
\hline \multirow[t]{2}{*}{ Logistic regression } & \multirow{2}{*}{$\begin{array}{l}4 \text { (Health centres HIV } \\
\text { status unknown) }\end{array}$} & \multirow[t]{2}{*}{203} & Age of first sexual intercourse ${ }^{a}$ & 0.86 & $0.68-1.07$ \\
\hline & & & Formal employment & 0.30 & $0.06-1.50$ \\
\hline \multirow[t]{3}{*}{ GEE } & \multirow[t]{3}{*}{1,23 and 4} & \multirow[t]{3}{*}{886} & Abortion & 1.60 & $0.97-2.63$ \\
\hline & & & $\geq 3$ lifetime sexual partners & 1.29 & $0.83-1.99$ \\
\hline & & & Chemicals for vaginal care & 0.65 & $0.37-1.14$ \\
\hline \multirow[t]{3}{*}{ Logistic regression } & \multirow[t]{3}{*}{3 and 4} & \multirow[t]{3}{*}{643} & Alcohol consumption & 1.76 & $0.80-3.86$ \\
\hline & & & $\geq 3$ lifetime sexual partners & 1.58 & $0.72-3.46$ \\
\hline & & & Plants for vaginal care & 2.70 & $1.04-7.01^{* *}$ \\
\hline
\end{tabular}

LSIL+: cytology findings compatible with (pre)cancerous lesions (includes low- and high-grade squamous intraepithelial lesions and carcinoma)

OR odds ratio; $95 \% \mathrm{Cl} 95 \%$ confidence interval of the odds ratio

GEE: generalized estimating equations (population-averaged model; group variable: study group)

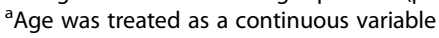

$\S$ Odds ratio could not be calculated because there were cells without observations

${ }^{*} P$-value of Wald test $<0.05$

typing: ASCUS, ASC-H, LSIL, HSIL or carcinoma. In the HIV-positive group, 50 out of the 52 ASCUS+ samples contained HPV DNA. HPV16 was found in 10 out of 50 samples, and HPV18 in 5 (Table 7). Other genotypes that were frequently detected were HPV35 $(n=12)$, HPV52 $(n=12)$, HPV68 $(n=12)$, HPV51 $(n=10)$, and HPV31 $(n=9)$. In the groups of women with negative or unknown HIV status, 50 samples were tested with INNO-LiPA of which 40 contained detectable HPV DNA (Table 7). Here, the most frequently detected genotypes were HPV52 ( $n=$ 10), HPV35 $(n=6)$, HPV16 $(n=3), \operatorname{HPV} 18 \quad(n=5)$,
HPV51 $(n=5)$, and HPV54 $(n=5)$. In addition to the three samples in which HPV16 was detected through the INNO-LiPA test, there were three samples in which both the Abbot Real Time and the GenoID test indicated the presence of HPV16.

In groups 2, 3 and 4, $55 \%$ of samples which tested positive for HPV DNA contained one single HPV type. Two genotypes were found in $23 \%$ of the samples, three genotypes in $9 \%$, four in $7 \%$ and more than four in $7 \%$ of HPV-DNA positive samples. In the HIV-positive group (group 1), a single HPV infection occurred only in 
Table 7 HPV genotyping results for women with ASCUS+ cytology

\begin{tabular}{|c|c|c|}
\hline HPV genotype & $\begin{array}{l}\text { Group } 1 \text { (HIV-positive } \\
\text { women) }\end{array}$ & $\begin{array}{l}\text { Groups 2, } 3 \text { and } 4 \text { (women } \\
\text { with unknown or negative } \\
\text { HIV status) }\end{array}$ \\
\hline & $\begin{array}{l}\text { Number of women } \\
\text { with ASCUS }+=52\end{array}$ & $\begin{array}{l}\text { Number of women with } \\
\text { ASCUS }+=133\end{array}$ \\
\hline & $\begin{array}{l}\text { Number of samples in } \\
\text { which HPV typing results } \\
\text { were available }=50\end{array}$ & $\begin{array}{l}\text { Number of samples in } \\
\text { which HPV typing results } \\
\text { were available }=40\end{array}$ \\
\hline 6 & $3(6 \%)$ & $0(0 \%)$ \\
\hline 11 & $2(4 \%)$ & $1(3 \%)$ \\
\hline 16 & $10(20 \%)$ & $3(8 \%)^{a}$ \\
\hline 18 & $5(10 \%)$ & $5(13 \%)$ \\
\hline 31 & $9(18 \%)$ & $2(5 \%)$ \\
\hline 33 & $6(12 \%)$ & $4(10 \%)$ \\
\hline 35 & 12 (24 \%) & $6(15 \%)$ \\
\hline 39 & $6(12 \%)$ & $4(10 \%)$ \\
\hline 40 & $1(2 \%)$ & 1 (3 \%) \\
\hline 43 & $2(4 \%)$ & $0(0 \%)$ \\
\hline 44 & $5(10 \%)$ & $0(0 \%)$ \\
\hline 45 & 7 (14 \%) & $2(5 \%)$ \\
\hline 51 & $10(20 \%)$ & $5(13 \%)$ \\
\hline 52 & 12 (24 \%) & $10(25 \%)$ \\
\hline 53 & $5(10 \%)$ & $1(3 \%)$ \\
\hline 54 & $3(6 \%)$ & $5(13 \%)$ \\
\hline 56 & $6(12 \%)$ & $3(8 \%)$ \\
\hline 58 & 7 (14 \%) & $0(0 \%)$ \\
\hline 59 & $2(4 \%)$ & $1(3 \%)$ \\
\hline 66 & $7(14 \%)$ & $4(10 \%)$ \\
\hline 68 & 12 (24 \%) & $3(8 \%)$ \\
\hline 69 & $1(2 \%)$ & 1 (3 \%) \\
\hline 70 & $5(10 \%)$ & 1 (3 \%) \\
\hline 74 & $4(8 \%)$ & $4(10 \%)$ \\
\hline 82 & $0(0 \%)$ & $1(3 \%)$ \\
\hline
\end{tabular}

HPV human papillomavirus

ASCUS+ includes: atypical squamous cells of undetermined significance (ASCUS); atypical squamous cells; cannot rule out high-grade lesion (ASC-H); low- grade squamous intraepithelial lesions (LSIL), high-grade squamous intraepithelial lesions (HSIL) and carcinoma

an addition to the three samples in which HPV16 was detected through the INNO-LiPA test, there were three samples in which both the Abbot Real Time and the GenolD test indicated the presence of HPV16

$20.0 \%$ of the samples. Two genotypes were found in $38 \%$, three in $9 \%$, four in $16 \%$ and more than four in $18 \%$ of the samples.

\section{Discussion}

The present study was performed to assess the prevalence of LSIL+ lesions and to identify associated factors in different groups of women in Kinshasa. The prevalence of LSIL+ lesions ranged from approximately $4 \%$ in women with unknown or negative HIV status to $31 \%$ in HIV-positive women. We found an association between the practice of intravaginal insertion of plants and the presence of LSIL+. HPV types 16 and 18 which are known to cause cervical cancer in many countries worldwide appear to be less predominant in women in Kinshasa.

The prevalence of LSIL+ lesions that we found in the current study in women with unknown or seronegative HIV status (4\%) is consistent with the few studies previously performed in Kinshasa (3\% and $5 \%$ ) [35, 36] and in Bukavu in the eastern part of the country (7\%) [37]. Numbers of the same order of magnitude have been published in other Sub-Saharan countries. A prevalence between 4 and $10 \%$ was found in studies in Burkina-Faso, Nigeria, Tanzania, South Africa, Malawi and Kenya [29, 41-49]. Higher prevalences (16\%) were reported in studies in the Central African Republic and Uganda [50, 51]. These reports and our findings highlight the high and heterogeneous frequency of (pre) cancerous lesions in different countries of Sub-Saharan Africa. Furthermore, in our study, lesions classified as ASCUS and ASC-H were also frequent (more frequent than LSIL+) among women with negative or unknown HIV status.

Cervical cancer is known to be more frequent among HIV-positive women. In the DRC, it is estimated that $1.9 \%$ of the adult women are HIV infected, with differences between women living in urban areas $(2.4 \%)$ and rural areas (1.0\%) [52]. We found a prevalence of LSIL+ lesions of $31 \%$ in HIV-seropositive women. This finding is consistent with an earlier result (27\%) described in a small group of seropositive women in Kinshasa [35]. Also in other Sub-Saharan countries (pre)cancerous lesions were about five times more frequent in HIV-positive than in HIV-negative women [41, 42, 45, 48-51, 53].

Several demographic, economical and behavioural risk factors have been studied in relation to cervical cancer. Most of them may influence the risk of cancer through their effects on the risk of HIV and HPV infection. In the current study, we found a significant association between the intravaginal application of plant products and the presence of LSIL+ lesions. It is a frequent practice in Sub-Saharan Africa to use herbs, leaves and bark of trees to reduce vaginal lubrication and increase friction during sexual intercourse (dry sex) [54-59]. The perception is that dry sex increases sexual enjoyment. A study in the DRC revealed that one third of the women had used intra-vaginal substances at some time [55]. Another Congolese study looked into how specific plants are used and what the chemical and microbiological consequence of this traditional practice could be [60].

Most of the studies about the vaginal use of plants have been done in relation to the risk of HIV infection. 
It has been hypothesised that differences in the vaginal environment may partially explain the different HIV transmission probabilities that are observed across populations [61]. Similar mechanisms may play a role in transmission and clearance of HPV [62-64]. The insertion of plant products and the increased friction during dry sex may alter the vaginal microbiota and cause traumatic microlesions in the vaginal wall facilitating the entry of HPV [62-64].

The association between HPV infection and cervical cancer is well established, but the specific HPV genotypes that are involved in neoplasia differ across populations. The HPV types that have been most frequently linked to cervical cancer are: 16, 18, 31, 33, 45, 52 and 58 [53, 65]. HPV16 and 18 are responsible for $70 \%$ of precancerous lesions and cervical cancer worldwide and consequently, these are the HPV types which the vaccine development has focused on. Nevertheless, our study suggests that HPV16 and 18 are less frequent (maximally $30 \%$ of women with ASCUS+) and that HPV types 35, 52 and 68 are more predominant than in other regions. Other studies in the DRC have also described specific patterns of HPV types [38, 40].

In other Sub-Saharan countries, the frequency of HPV16 and 18 varies. Some countries have reported patterns that resemble the situation in Europe and the United States [22, 48, 66, 67], whereas in other countries, HPV types other than 16 and 18 appear to be more prominent $[29,47,68,69]$.

The DRC is a large country that is facing many complex problems at the same time. As a consequence, cervical cancer is not getting the attention that would be required for adequate disease control. Yet, the burden caused by cervical cancer in the DRC would justify a coordinated control strategy. This study together with a previous report illustrates that women in Kinshasa are willing to participate in prevention and control activities [70]. Interventions that could help to reduce the morbidity and mortality of cervical cancer include vaccination for HPV, systematic screening and early treatment. The effectiveness of such interventions may benefit from further research into the epidemiology of oncogenic HPV types and modifiable risk factors such as the use of plants for intimate care.

\section{Conclusion}

Our work illustrates that the prevalence of (pre)cancerous lesions in women from different districts in Kinshasa is approximately $4 \%$. In HIV-positive women, the prevalence is about eight times higher. Traditional practices concerning vaginal hygiene may increase the risk of malignant transformation. More extensive studies, including rural areas, are needed to unravel the contribution of different HPV types in the development of cervical cancer.

\section{Methods}

\section{Study design, setting and participants}

We performed a cross-sectional study on the prevalence of precancerous and cancerous lesions of the uterine cervix in four groups of women in Kinshasa. The first two groups consisted of women who participated in a voluntary screening programme for HIV in the ACS/ AMO-CONGO centre (Action Communautaire contre le Sida/Avenir Meilleur pour les Orphelins du Sida au Congo) and in the Centre Hospitalier Monkole 3. Women who visited these centres for HIV screening and care between September 2006 and January 2007 were invited to participate in free cervical cancer screening. The first group $(n=131)$ consisted of women who were found to be seropositive for HIV; the second group $(n=128)$ consisted of HIV-seronegative women. The diagnosis of HIV was based on two rapid tests (Determine ${ }^{\circ} \mathrm{HIV}-1 / 2$ (Abbott) and OraQuick HIV-1/2 (OraSure Technologies)) combined with one of the following serological tests: Vironostika ${ }^{\circ}$ Uni-Form II Plus O (BioMérieux), Enzygnost ${ }^{\circ}$ Anti-HIV $1 \frac{2}{2}$ Plus (Siemens), or Inno-Lia HIVI/II Score (Inno-LIA ${ }^{\circ}$, Innogenetics). The third group $(n=539)$ consisted of women who consulted the gynaecology department of the Provincial Reference Hospital of Kinshasa (Hôpital Provincial Général de Référence de Kinshasa, HPGRK) and the Ngaliema hospital. Both hospitals are large state hospitals in the centre of the city. Data were collected from July to August 2009. At that time, a sensitisation campaign for free cervical screening was broadcast on television, posters advertising cervical cancer screening were shown at the hospitals, and a symposium on cervical cancer took place at the HPGRK. The participants of the fourth group $(n=220)$ were recruited via primary health care centres in the communities of Kimbanseke, Kisenso, Ndjili and Lemba, located in the poorer suburbs of the city. Data were collected from September 2012 to January 2013 after a campaign in local churches for free cervical cancer screening.

All women older than 17 who were willing to participate in the study and for whom a liquid-based cytology (LBC) result was available were included in the analysis.

\section{Variables, data sources and measurement Cytology}

Cytology was the main outcome variable. Cervical smears were collected with Cervex Brush and conserved in ThinPrep solution for LBC and HPV typing. Samples were kept at $4{ }^{\circ} \mathrm{C}$. ThinPrep vials were transferred to the Pathology Laboratory of the University Hospital of Ghent, Belgium, for further analysis. The collected smears were independently read and interpreted by two pathologists. The pathologists were not aware of the HIV and HPV status at the time of reading the microscopy slides. In case of discrepancy, the slides were reread by both pathologists 
for a final interpretation. The cytology results were reported according to the Bethesda Classification 2001 of cervical pathology. Women with cytology results indicating LSIL (low-grade squamous intraepithelial lesion), HSIL (high-grade squamous intraepithelial lesion) and invasive carcinoma were considered to have precancerous or cancerous lesions and classified as LSIL+ (according to [71]). Women with ASCUS (atypical squamous of undetermined significance), ASC-H (atypical squamous, cannot rule out high-grade lesion) results or worse (ASCUS+) underwent HPV-DNA determination. Women with NILM (negative for intraepithelial lesion and malignancy) or inflammation were considered to be free of cancer.

\section{Determination of HPV DNA and HPV typing}

HPV typing was done in participants with ASCUS+ cytology results. Samples from women with ASCUS and ASC- $\mathrm{H}$ were included in the HPV evaluation as the European guidelines recommend to determine HPV DNA in these groups. INNO-LiPA HPV Genotyping Extra (Innogenetics, Zwijnaarde, Belgium) was used for HPV typing. It is molecular technique based on the principle of reverse hybridisation designed to recognize fifteen highrisk HPV types $(16,18,31,33,35,39,45,51,52,56,58$, 59, 68, 73 and 82), three probable high-risk HPV types (26, 53 and 66), seven low-risk HPV types $(6,11,40,43$, 44, 54 and 70) and three non-classified HPV types (69, 71 and 74).) The testing strategies varied across the study groups. In groups 1 and 2, INNO-LiPA Genotyping was done for all ASCUS+ cases. In groups 3 and 4, the INNOLiPA test, due to its high cost, was only done if two other tests gave discordant results (Abbott Real Time High Risk HPV test (Abbott, Madison, USA) and Full Spectrum PCR HPV Amplification and Detection/Genotyping System (GenoID Molecular Diagnostics Laboratory, Budapest, Hungary)). We present all available INNOLiPA results because this test detects many different HPV types [72]. Concordant Abbott and GenoID results for HPV16 and HPV18 are also reported.

\section{Socio-economic, gynaecological/medical and behaviour variables}

Socio-economic and behaviour characteristics that were studied in association with the presence or absence of LSIL+ were: age, age of menarche, age of first sexual contact, marital status, formal employment, life-time number of sexual partners, use of products for vaginal care (chemicals and products from plants), alcohol consumption (no alcohol versus any consumption), number of pregnancies, number of childbirths, and history of abortion (without discrimination between spontaneous or provoked). Concerning the practice of intravaginal application of plants, information was only available for groups 3 and 4 .
The variables "age", "age of menarche" and "age of first sexual contact" follow a relatively normal distribution and are presented and analysed as continuous variables. The variables "number of sexual partners", "number of pregnancies" and "number of deliveries" follow a clearly abnormal distribution and are presented and analysed as categorical variables.

Information about the socio-economic situation and behaviour characteristics was obtained through a structured interview by medical doctors. Interviewers followed a training session before the start of the study.

\section{Statistical analysis}

The prevalence of LSIL+ lesions with $95 \%$ confidence intervals (95\% CI, Wilson score method without continuity correction) is reported for each of the four groups. Next, we used bivariate and multiple logistic regression to assess the association between socio-demographic and behaviour variables and the presence of LSIL+ lesions within each of the four groups. Finally, we analysed all participants together using generalized estimating equations (GEE) to account for clustering within the groups. The results of all logistic regression and GEE analyses are reported as odds ratios (OR) with $95 \%$ confidence intervals $(95 \% \mathrm{CI})$. Data was missing for some participants in some of the explanatory variables; for each of the analyses, the number of included participants is given. We used Stata/IC 10.1 for data analysis.

\section{Ethical considerations}

The study protocol on the collection of data and the reporting of data to participants was approved by the Ethics Committee of the School of Health of the University of Kinshasa. After having explained the objectives of the study, all study participants signed a document of informed consent.

\section{Competing interests \\ The authors declare that they have no competing interests.}

\section{Authors' contributions}

CAR: is the main investigator and participated in the design of the study, data collection and interpretation, analysis and writing. KV: participated in the statistical analysis, drafting and revision of the manuscript. EP. participated in data collection and interpretation, and in revision of the manuscript. DVB: participated in data analysis and interpretation and critically revised the manuscript. MP: helped in the design and the interpretation and gave final approval of the version to be published. All authors read and approved the final manuscript.

\section{Acknowledgements}

Our thanks go to the Belgian Cooperation for Development, the Flemish Interuniversity Council for Development Cooperation, and the Alumni Association of the Faculty of Medicine of the University of Leuven for scholarships for C. Ali-Risasi.

\section{Author details}

${ }^{1}$ Laboratory of Anatomopathology, General Reference Hospital of Kinshasa, Kinshasa, Democratic Republic of the Congo. ${ }^{2}$ N.Goormaghtigh Institute of Pathology, Ghent University Hospital, De Pintelaan 185, Ghent, Belgium. 
${ }^{3}$ Institute of Tropical Medicine, Nationalestraat 155, Antwerp, Belgium. ${ }^{4}$ Department of Microbiology, Clinical Chemistry and Immunology, Ghent University Hospital, De Pintelaan 185, Ghent, Belgium. ${ }^{5}$ Faculty of Medicine and Life Sciences, Hasselt University, Agoralaan Building D, Diepenbeek, Belgium. ${ }^{6}$ International Centre for Reproductive Health, Ghent University Hospital, De Pintelaan 185, Ghent, Belgium.

\section{Received: 31 January 2015 Accepted: 25 June 2015} Published online: 15 July 2015

\section{References}

1. Ferlay J, Shin HR, Bray F, Forman D, Mathers C, Parkin DM. Estimates of worldwide burden of cancer in 2008:GLOBOCAN 2008. Int J Cancer. 2010;127:2893-917.

2. Arbyn M, Castellsague $X$, De Sanjose S, Bruni L, Saraiya M, Bray F, et al. Worldwide burden of cervical cancer in 2008. Ann Oncol. 2011;22:2675-86.

3. Jemal A, Bray F, Forman D, O'Brien M, Ferlay J, Center M, et al. Cancer burden in Africa and opportunities for prevention. Cancer. 2012;118:4372-84.

4. Parkin DM, Sitas F, Chrirenje M, Stein L, Abratt R, Wabinga H. Part I: Cancer in Indigenous Africans-burden, distribution, and trends. Lancet Oncol. 2008:9:683-92

5. Louie KS, de Sanjose S, Mayaud P. Epidemiology and prevention of human papillomavirus and cervical cancer in sub-Saharan Africa: a comprehensive review. Trop Med Int Health. 2009;14:1287-302.

6. Denny L. Cervical cancer treatment in Africa. Curr Opin Oncol. 2011;23:469-74

7. Sylla BS, Wild CP. A million africans a year dying from cancer by 2030: what can cancer research and control offer to the continent? Int J Cancer 2012;130:245-50.

8. Peto J, Gilham C, Fletcher O, Mattews FE. The cervical cancer epidemic that screening has prevented in the UK. Lancet. 2004;364:249-56.

9. Bray F, Jemal A, Grey N, Ferlay J, Forman D. Global cancer transitions according to the Human Development Index (2008-2030): a population-based study. Lancet Oncol. 2012;13:790-80.

10. Plummer $\mathrm{M}$, Peto J, Franceschi $\mathrm{S}$, the International Collaboration of Epidemiological Studies of Cervical Cancer. Time since first sexual intercourse and the risk of cervical cancer. Int J Cancer. 2012;130:2638-44.

11. Franceschi S, Herrero R, Clifford GM, Snijders PJ, Arslan A, Anh PT, et al. Variations in the age-specific curves of human papillomavirus prevalence in women worldwide. Int J Cancer. 2006;119:2677-84.

12. Kjellberg L, Hallmans G, Ahren AM, Johansson R, Bergman F, Wadell G, et al. Smoking, diet, pregnancy and oral contraceptive use as risk factors for cervical intra-epithelial neoplasia in relation to human papillomavirus infection. Br J Cancer. 2000;82:1332-38.

13. Castellsague $X$, Munoz N. Cofactors in human papillomavirus carcinogenesis-role of parity, oral contraceptives, and tobacco smoking. J Natl Cancer Inst Monogr. 2003;31:20-8.

14. Applebey P, Beral V, Berrington de Gonzalez A, Colin D, Franceschi S, Goodhill A, et al. Cervical cancer and hormonal contraceptives:collaborative reanalysis of individual data for 16, 573 women with cervical cancer and 35, 509 women without cervical cancer from 24 epidemiological studies. Lancet. 2007;370:1609-21.

15. Applebey P, Beral V, Berrington de Gonzalez A, Colin D, Franceschi S, Goodhill A, et al. Carcinoma of the cervix and tobacco smoking:collaborative reanalysis of individual data on 13, 541 women with carcinoma of the cervix and 23,017 women without carcinoma of the cervix from 23 epidemiological studies. Int J Cancer. 2007;118:1481-95.

16. Denny LA, Franceschi S, De Sanjose S, Heard I, Moscicki AB, Palefsky J. Human papillomavirus, human immunodeficiency virus and immunosuppression. Vaccine. 2012;30 Suppl 5:168-74.

17. De Vuyst H, Mugo NR, Chung MH, Mckenzie KP, Nyongesa-malava E, Tenet $\checkmark$, et al. Prevalence and determinants of human papillomavirus infection and cervical lesions in HIV-positive women in Kenya. Br J Cancer. 2012;107:1624-30.

18. De Vuyst H, Ndirangu G, Moodley M, Tenet V, Estambale B, Meijer CJ, et al. Prevalence of human papillomavirus in women with invasive cervical carcinoma by HIV status in Kenya and South Africa. Int J Cancer 2012;131:949-55.

19. Walboomers JM, Jacobs MV, Manos MM, Bosch FX, Kummer JA, Shah KV, et al. Human papillomavirus is a necessary cause of invasive cervical cancer worldwide. J Pathol. 1999:189:12-9.
20. Schiffman M, Castle PE, Jeronimo J, Rodriguez AC, Wacholder S. Human papillomavirus and cervical cancer. Lancet. 2007;370:890-907.

21. Bosch FX, Lorincz A, Munoz N, Meijer CJ, Shah KV. The causal relation between human papillomavirus and cervical cancer. J Clin Pathol. 2002;55:244-65.

22. Denny L, Adewole I, Anorlu R, Dreyer G, Moodley M, Smith T, et al. Human papillomavirus prevalence and type distribution in invasive cervical cancer in sub-Saharan Africa. Int J Cancer. 2014;134:1389-98.

23. Munoz N, Bosch FX, De Sanjose S, Herrero R, Castellsague X, Shah KV, et al. IARC Multicenter Cervical Cancer Study Group: Epidemiologic classification of human papillomavirus types associated with cervical cancer. N Engl J Med. 2003;348:518-27.

24. Munoz N, Castellsague X, De Gonzalez AB, Gissmann L. HPV in the etiology of human cancer. Vaccine. 2006;24 Suppl 3:1-10.

25. Crosbie EJ, Einstein MH, Franceschi S, Kitchener HC. Human papillomavirus and cervical cancer. Lancet. 2013;382:889-99.

26. Bouvard V, Baan R, Straif $K$, Grosse $Y$, Secretan B, El Ghissassi FWHOIARC. Monograph Working Group: A review of human carcinogens-Part B: biological agents. Lancet Oncol. 2009;10:321-22.

27. Bruni L, Diaz M, Castellsague X, Ferrer E, Bosch FX, De Sanjose S. Cervical human papillomavirus prevalence in 5 continents: meta-analysis of 1 million women with normal cytological findings. J Infect Dis. 2010;202:1789-99.

28. de Sanjose S, Quint WG, Alemany L, Geraets DT, Klaustermeier JE, Lloveras B, et al. Human papillomavirus genotype attribution in invasive cervical cancer:a retrospective cross-sectional worldwide study. Lancet Oncol. 2010;11:1048-56.

29. De Vuyst H, Parisi MR, Karani A, Mandaliya K, Muchiri L, Vaccarella S. The prevalence of human papillomavirus infection in Mombasa, Kenya. Cancer Causes Control. 2010;21:2309-13.

30. Ndiaye C, Alemany L, Ndiaye N, Kamate B, Diop Y, Odida M, et al. Human papillomavirus distribution in invasive cervical carcinoma in sub-Saharan Africa:could HIV explain the differences? Trop Med Int Health. 2012;17:1432-40.

31. El-Khatib Z, Tota JE, Kaufmann AM. Progress on human papillomavirus (HPV) infection and cervical cancer prevention in sub-Saharan Africa: highlights of the 27th International Papillomavirus Conference in Berlin. J Epidemiol Glob Health. 2012:2:99-102.

32. Maranga IO, Hampson L, Oliver AW, He X, Gichangi P, Rana F, et al. HIV Infection Alters the Spectrum of HPV Subtypes Found in Cervical Smears and Carcinomas from Kenyan Women. Open Virol J. 2013;7:19-27.

33. Gakidou E, Nordhagen S, Obermeyer Z. Coverage of cervical cancer screening in 57 countries:low average levels and large inequalities. PLoS Med. 2008:5, e132

34. Anorlu RI. Cervical cancer:the Sub-Saharan African perspective. Reprod Health Matters. 2008;16:41-9.

35. Laga M, Icenogle JP, Marsella R, Manoka AT, Nzila N, Ryder RW, et al. Genital papillomavirus infection and cervical dysplasia-opportunistic complications of HIV infection. Int J Cancer. 1992:50:45-8.

36. Sangwa-Lugoma G, Mahmud S, Nasr SH, Liaras J, Kayembe PK, Tozin RR, et al. Visual inspection as a cervical cancer screening method in a primary health care setting in Africa. Int J Cancer. 2006;119:1389-95.

37. Hovland S, Arbyn M, Lie AK, Ryd W, Borge B, Berle EJ, et al. A comprehensive evaluation of the accuracy of cervical pre-cancer detection methods in a high-risk area in East Congo. Br J Cancer. 2010;102:957-65.

38. Sangwa-Lugoma G, Ramanakumar AV, Mahmud S, Liaras J, Kayembe PK, Tozin RR, et al. Prevalence and determinants of high-risk human papillomavirus infection in women from a sub-Saharan African community. Sex Transm Dis. 2011:38:308-15.

39. Mahmud S, Sangwa-Lugoma G, Nasr SH, Kayembe PK, Tozin RR, Drouin P, et al. Comparison of human papillomavirus testing and cytology for cervical cancer screening in a primary health care setting in the Democratic Republic of the Congo. Gynecol Oncol. 2012;124:286-91.

40. Icenogle JP, Laga M, Miller D, Manoka AT, Tucker RA, Reeves W. Genotypes and sequence variants of human papillomavirus DNAs from human immunodeficiency virus type 1-infected women with cervical intraepithelial neoplasia. J Inf Dis. 1992;166:1210-16.

41. Anorlu RI, Igwilo Cl, Aknamu AS, Banjo AA, Odunukwe NN, Okany CC, et al. Prevalence of abnormal cervical smears among patients with HIV in Lagos, Nigeria. West Afr J Med. 2007;26:143-47.

42. Dim CC, Ezegwui HU, Ikeme AC, Nwagha UI, Onyedum CC. Prevalence of cervical squamous intraepithelial lesions among HIV-positive women in Enugu, South-eastern Nigeria. J Obstet Gynaecol. 2011;31:759-62. 
43. Durowade KA, Osagbemi GK, Salaudeen AG, Musa Ol, Akande TM, Babatunde OA. Prevalence and risk factors of cervical cancer among women in an urban community of Kwara State, north central Nigeria. J Prev Med Hyg. 2012;53:213-19.

44. Pimentel VM, Jiang X, Mandavilli S, Umenyinwana C, Schnatz PF. Prevalence of high-risk cervical human papillomavirus and squamous intraepithelial lesion in Nigeria. J Low Genit Tract Dis. 2013;17:203-9.

45. Obure J, Olala O, Swai B, Mlay P, Masenga G, Walmer D. Prevalence and severity of cervical squamous intraepithelial lesion in a tertiary hospital in northern Tanzania. Tanzania J Health Res. 2009:11:163-69.

46. Fonn S, Bloch B, Mabina M, Carpenter S, Cronje H, Maise C, et al. Prevalence of pre-cancerous lesions and cervical cancer in South Africa-a multicentre study. S Afr Med J. 2002;92:148-56.

47. Didelot-Rousseau MN, Nagot N, Costes-Martineau V, Valles X, Ouedraogo A Konate I, et al. Human papillomavirus genotype distribution and cervical squamous intraepithelial lesions among high-risk women with and without HIV-1 infection in Burkina Faso. Br J Cancer. 2006;95:355-62

48. Motti PG, Dallabetta GA, Daniel RW, Canner JK, Chiphangwi JD, Liomba GN, et al. Cervical abnormalities, human papillomavirus, and human immunodeficiency virus infections in women in Malawi. J Infect Dis. 1996:173:714-17.

49. Luchters S, Vanden Broeck D, Chesich MF, Nel A, Delva W, Mandaliya K, et al. Association of HIV infection with distribution and viral load of HPV types in Kenya:a survey with 820 female sex workers. BMC Infect Dis. 2010;10:18.

50. Koffi B, Serdouma E, Mbolissa-Nguérékoudou W, Ngadjou-Kouchou-Fondjo M, Pengoussou-Gbatoumba V, Pengoussou-Gbatoumba V. Cervical dysplasia in women with human immunodeficiency virus (HIV) in areas of high prevalence of infection. Gynecol Obstet Fertil. 2010;38:576-80.

51. Blossom DB, Beigi RH, Farrell JJ, Mackay W, Qadadri B, Brown DR, et al. Human papillomavirus genotypes associated with cervical cytologic abnormalities and HIV infection in Ugandan women. J Med Virol. 2007;79:758-65.

52. USAID/GLOBAL HEALTH. HIV Prevalence Results from the Democratic Republic of Congo 2007. http://dhsprogram.com/pubs/pdf/HF25/HF25.pdf. Accessed 22 May 2015

53. Clifford GM, Smith JS, Aguado T, Franceschi S. Comparison of HPV type distribution in high-grade cervical lesions and cervical cancer:a meta-analysis. Br J Cancer. 2003;101-5.

54. Hilber MA, Hull TH, Preston-Whyte E, Bagnol B, Smit J, Wacharasin C. A cross sectional study of vaginal practices and sexuality:implications for sexual health. Soc Sci Med. 2010;70:392-400

55. Brown JE, Ayowa OB, Brown RC. Dry and tight: sexual practices and potential AIDS risk in Zaire. Soc Sci Med. 1982;37:989-94.

56. Civic D, Wilson D. Dry sex in Zimbabwe and implications for condom use. Soc Sci Med. 1982:42:91-8.

57. Beksinska ME, Rees HV, Kleinschmidt I, Mclntyre J. The practice and prevalence of dry sex among men and women in South Africa:a risk factor for sexually transmitted infections? Sex Transm Infect. 1999;75:178-80.

58. Myer L, Denny L, De Souza M, Wrigth Jr TC, Kuhn L. Distinguishing the temporal association between women's intravaginal practices and risk of human immunodeficiency virus infection: a prospective study of South African women. Am J Epidemiol. 2006;163:552-60.

59. Scorgie F, Kunene B, Smit JA, Manzini N, Chersich MF, Preston-Whyte EM. In search of sexual pleasure and fidelity: vaginal practices in KwaZulu-Natal, South Africa. Cult Health Sex. 2009;11:267-83.

60. Kabena Ngandu O, Luyeye Lukoki F, Mpiana TP, Ngombe KN, Ruphin PF, Robijaona B, et al. Pytochemical screening of some medicinal plants traditionally used by African women in Kinshasa city (DR Congo for their intimate hygiene and evaluation of the $\mathrm{pH}$ of derived recipes). J Modern Drug Discovery Drug Delivery Res. 2014;1:1-7.

61. Buvé A, Jespers V, Crucitti T, Fichorova RN. The vaginal microbiota and susceptibility to HIV. AIDS. 2014;28:2333-44.

62. Gillet E, Meys JF, Verstraelen H, Bosire C, De Sutter P, Temmerman M. Bacterial vaginosis is associated with uterine cervical human papillomavirus infection:a meta-analysis. BMC Inf Dis. 2011;11:10

63. King CC, Jamieson DJ, Wiener J, Cu-Uvin S, Klein RS, Rompalo AM. Bacterial vaginosis and the natural history of human papillomavirus. Infect Dis Obstet Gyncecol. 2011;2011:319460.
64. Gillet E, Meys JF, Verstraelen H, Verhelst R, De Sutter P, Temmerman M Association between bacterial vaginosis and cervical intraepithelial neoplasia:systematic review and meta-analysis. PLoS One. 2012;7, e45201.

65. Clifford GM, Smith JS, Plummer M, Munoz N, Franceschi S. Human papillomavirus types in invasive cervical cancer worldwide: a meta-analysis Br Cancer. 2003;88:63-73.

66. Carrilho C, Cirnes L, Alberto M, Buane L, Mendes N, David L. Distribution of HPV infection and tumour markers in cervical intraepithelial neoplasia from cone biopsies of Mozambican women. J Clin Pathol. 2005;58:61-8.

67. Dartell M, Rasch V, Munk C, Kahesa C, Mwaiselage J, Iftner T, et al. Risk Factors for High-Risk Human Papillomavirus Detection among HIV-Negative and HIV-Positive Women from Tanzania. Sex Transm Dis. 2013;40:737-43.

68. Luque AE, Hitti J, Mwachari C, Lane C, Messing S, Cohn SE. Prevalence of human papillomavirus genotypes in HIV-1-infected women in Seattle, USA and Nairobi, Kenya: results from the Women's HIV Interdisciplinary Network (WHIN). Int J Infect Dis. 2010;14:e810-4.

69. Veldhuijzen NJ, Braunstein SL, Vyankandondera J, Ingabire C, Ntirushwa J,

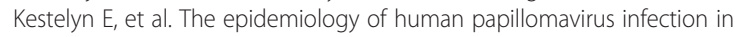
HIV-positive and HIV-negative high-risk women in Kigali, Rwanda. BMC Infect Dis. 2011;11:333.

70. Ali-Risasi C, Mulumba P, Verdonck K, Vanden Broeck D, Praet M. Knowledge, attitude and practice about cancer of the uterine cervix among women living in Kinshasa, the Democratic Republic of the Congo. BMC Women's Health. 2014;14:30

71. Wright TC, Ronnett BM, Kurman RJ, Ferenczy A. (Pre)cancerous lesions of the cervix. In Kurman RJ, Ellenson HL, Ronnett BM, editors. Blaustein's Pathology of the Female Genital Tract: Springer; New York, USA 2011. p 193-252.

72. Padalko E, Ali-Risasi C, Mesmaekers S, Ryckaert I, Van Renterghem L, Lambein K, et al. Comparative analysis of cervical cytology and HPV genotyping by three different methods in routine diagnostic setting. Eur J Cancer Prevention, 2014 November 3 (Epub ahead of print).

\section{Submit your next manuscript to BioMed Central and take full advantage of:}

- Convenient online submission

- Thorough peer review

- No space constraints or color figure charges

- Immediate publication on acceptance

- Inclusion in PubMed, CAS, Scopus and Google Scholar

- Research which is freely available for redistribution 